\title{
INSCRIBING INTERIORITY AND IDEOLOGY: REPRESENTING THE VISUALLY ELUSIVE IN THE AMERICAN Petroleum Institute's Cold WAR Films
}

\author{
ILA TYAGI
}

\section{Introduction}

The Cold War paranoia characteristic of the 1940s and 1950s bleeds into both fictional and nonfictional films made in the years immediately after the Second World War. Hollywood films like Invasion U.S.A. (1952), On the Beach (1959), and The Manchurian Candidate (1962) reflect salient concerns of the time, including defending national borders from Soviet encroachment, nuclear annihilation, and American brainwashing by insidious communist agents. The Cold War context is equally important for mid-century sponsored filmmaking. A 1956 film sponsored by the American Petroleum Institute (API), Destination Earth, begins on Mars, the "red planet" serving as a parody of the "Red" Soviet Union. Most films sponsored by the API, the oil industry's leading trade association, are black-and-white documentaries, but Destination Earth is a vivid Technicolor animation. It brackets its account of real-life oil-industry operations with a fictional framing narrative involving a Martian being sent to Earth by his planet's totalitarian dictator, Ogg the Exalted, to find a more efficient fuel source than the captive labor currently in use. To generate energy, Martians bound in chains have to trudge on paddle wheels similar to the punitive rotating treadmills used in jails in Victorian Britain.

Filmmaking sponsored by the American oil industry was part of a broader nonfiction educational film movement that developed parallel to the Hollywood studio system. Every imaginable American industry-including agriculture, automobiles, canning, chemicals, electricity, firearms, insurance, shipping, steel, and telecommunications - released sponsored educational films, either for private viewing by their own employees, or to screen widely for members of the public. The internally produced and distributed films were used in training, or to introduce employees to new products and services to sell. Films for public viewing taught audiences how a particular industry worked, highlighting its contributions to the American economy and way of life. Unlike 
advertisements, educational films for the public often did not endorse a specific product, or even mention the sponsor by name, but were designed simply to boost generalized goodwill toward the industry in question. They were frequently projected in nontheatrical venues like churches, schools, and women's group meetings. The heyday of sponsored filmmaking spanned the 1940 s and 1950s, but the sum total of films funded by industries and institutions before, during, and after that midcentury moment is an estimated 300,000 , "far more than any other type of motion picture."

The API-sponsored Destination Earth pits communist dourness against capitalist flourishing, showing the Martian aliens to be poor and browbeaten, whereas Earthlings living in the United States of America are prosperous and happy. A Martian crowd is frogmarched into a stadium to listen to their "Glorious Leader" pontificating, in a manner reminiscent of Soviet parades punctuated with dull speeches by party officials. The Martians cannot own private businesses, and their science and technology are primitive. When Ogg's emissary, Colonel Cosmic, reaches Earth, he discovers that the American economic system is as robust as it is because hundreds of privately owned oil companies compete with each other to find new oil reserves, and harness sophisticated science and technology to transform crude into an ever-expanding array of consumer products, from asphalt to gasoline to heating oil. The film underscores the impossibility of decoupling oil from the high American standard of living, strongly implying that the oil industry is the foundation of the Free World. Any measures to inhibit free business enterprise and introduce a Soviet-style state-regulated economic model will result in scarcity and suffering.

As part of its effort to contrast American superiority against Soviet inferiority, the film invokes high-minded American values like independence, daring, and hardiness. Destination Earth's voiceover explains that finding oil is a gamble, a game not for the faint of heart. Though "petroleum products are easily found anywhere, petroleum itself is a very elusive substance," as almost all oil lies far beneath the surface of the Earth and wells must stretch down thousands of feet to reach it. The film illustrates the seismic survey process by which oil companies "constantly" search for the fuel "in all the most likely and unlikely places," with a van shown setting off dynamite explosions above a cross-section of layers of underground rock. The van roams through a variety of landscapes with the cutaway layers of rock below, including a Southwestern desert, fitting the oil industry into the archetypal cultural image of a tough

\footnotetext{
${ }^{1}$ Rick Prelinger, The Field Guide to Sponsored Films (San Francisco: National Film Preservation Foundation, 2006), vi.
} 
cowboy boldly conquering the frontier on his own. ${ }^{2}$ The voiceover says that wells are expensive to drill, yet offer no guarantee of finding oil: in exploratory drilling, "only one well in nine finds any oil at all. Only one in forty-four recovers enough oil to pay for itself. And only one in almost a thousand makes a major discovery." "3espite these odds, America's oil supply keeps rising steadily, because the country allows any individual citizen resilient enough to assume the risks to prospect for oil.

Underground rock containing a fuel that drives the world, in other words, is a crucial site of struggle, the battleground where capitalist and communist values duke it out. Subterranean geology is hard to see, since most of us spend our lives confined to the surface of the Earth. However, API films like Destination Earth use the power of moving images to represent aspects of reality normally hidden from view. In this essay, I argue that by harnessing moving images' power to visualize the optically elusive, films sponsored by the oil industry show it to have technological access to customarily inaccessible underground space, thus making the industry seem a more potent foil for the communist menace. The fact that American oil prospectors are free to sink as many drill pipes into the ground as they can afford makes them superior to Soviet oil prospectors who do not stand to enrich themselves from similar endeavors (assuming they even have the technological prowess to do so), and who, due to the lack of competition endemic to left-wing economies, have no incentive to find and develop more oil and derivative products faster and better. Considering how API films illuminate the material dynamics of capitalism helps us better understand how to make abstract ideologies concrete. Where, geographically, might we be able to locate capitalism? In subterranean rock, a frontier that films sponsored by the oil industry suggest is only open to those who benefit from a capitalist system promising private ownership, light government regulation, and unlimited technological progress and economic growth.

I begin the essay with a brief overview of ideas in extant scholarship inspiring it. I then examine the overlap between seismic and motion-picture technology as the oil industry set about visualizing the increasingly complex geological data it gathered through its underground exploration. Visualizing underground exploration and other optically elusive phenomena anchors the

\footnotetext{
${ }^{2}$ For more on frontier imagery and fossil fuels, see Michael Watts, "Oil Frontiers: The Niger Delta and the Gulf of Mexico," in Oil Culture, eds. Ross Barrett and Daniel Worden (Minneapolis, MN: University of Minnesota Press, 2014), 189-210.

3 "Destination Earth," Internet Archive, accessed March 1, 2018, https://archive.org/details/Destinat1956.
} 
API films I analyze in the final section. These films were commissioned for an annual nationwide event promoting public understanding of the petroleum industry, Oil Progress Week, alongside a barrage of other public-relations materials. Held throughout the decade between 1948 and 1958, Oil Progress Week was one piece in a pervasive campaign undertaken by corporate America to assert its dominance in every realm, from culture, to economics, to politics, society, and technology, and to win over public favour for the capitalist ethos.

\section{Graduating From the Tangible to the Abstract}

In her study of Alfred Hitchcock's The Wrong Man (1956), Noa Steimatsky, channeling Jean-Luc Godard, posits that human faces onscreen come "to enfold a promise of interiority." That is, by focusing on the motile visual surfaces of an actor's face, we can pass through it as through a porous screen, arriving at intangible phenomena that are difficult to visually represent, such as the thoughts or emotions of the character being portrayed. Accessing the intangible or difficult to represent through the tangible and representable is a key strategy for the oil industry-sponsored films I discuss in this essay, as phenomena that are challenging to visually depict are thickly clustered within this particular business. Slowly unfolding disasters like marine oil spills and planet-pervading industry infrastructure, for example, are difficult to represent due to the long timelines and large space involved. ${ }^{5}$ Underground rock and capitalist ideology pose a similar representational challenge because subterranean geology is usually inaccessible to us without technological intervention, and because "capitalism" is abstract. However, visual tools like seismograms and animation help to visually render underground rock. Their renderings of tangible geology allow us, the viewers, to pass through the material rock, as through the aforementioned porous filter, and approach a representation of ineffable capitalism.

The photographer Allan Sekula has made a career out of reaching for immaterial ideologies that are revealed by and exceed the material detail. His book Fish Story, for instance, collects images of surfaces in industrial maritime transport, such as the outsides of tankers and shipping containers. These photographs of concrete manifestations of an abstract global economy attempt to lead the viewer, through visible details, into the realm of the invisible system

\footnotetext{
${ }^{4}$ Noa Steimatsky, "What The Clerk Saw: Face To Face With The Wrong Man," Framework 48, no. 2 (Fall 2007): 111.

${ }^{5}$ See Rob Nixon, Slow Violence and the Environmentalism of the Poor (Cambridge, MA: Harvard University Press, 2011).
} 
lying beyond them. ${ }^{6}$ Piercing through the visible to access what lies beyond works on two levels in the case of petroleum geology. Firstly, seismic surveys penetrate visible ground surface to access the Earth's visually elusive interior. Secondly, accessing that visually elusive, yet still tangible, underground rock enables us to graduate to accessing an intangible economic ideology. Distilling the visually elusive into the visible has the effect of taming it, making its unruliness easier to grasp. Rooting an abstract concept like capitalism within visualizable underground rock allows for its complexity to be compactly packaged and relayed to media viewers. API films were designed to quickly and simply persuade their audiences that capitalism was a more effective economic system than communism, necessitating this kind of condensation.

Capitalism is thus difficult, but not impossible, to represent. Jacques Rancière has argued that the unrepresentable is "lodged" in the "impossibility of an experience being told in its own appropriate language."7 In other words, capitalism would be unrepresentable if we could not find a language peculiar to it. However, through their reduction of capitalism's complexity into a standardized commodity, the visible image, that is then circulated to consumers like any other industrial product, API films borrow some of the vocabulary of the capitalist system, using its own logic to successfully represent it. ${ }^{8}$ Their high degree of standardization means that rhetorical and stylistic patterns are regularly repeated across the films, with only slight variations. Educational films sponsored by industries comprise a vast, yet understudied, corpus in motion-picture history, perhaps because their similarity to each other and bluntly propagandistic tone makes them easy to dismiss as hackneyed. As Vinzenz Hediger and Patrick Vonderau say in one of the few book-length accounts of sponsored filmmaking, Films That Work, industrial images are "typically overabundant rather than scarce and therefore are condemned to a fate of devaluation."9 I believe, though, that industrial films have much to teach

\footnotetext{
${ }^{6}$ Allan Sekula, Fish Story (Düsseldorf: Richter Verlag, 2002), 12.

${ }^{7}$ Jacques Rancière, The Future of the Image (New York: Verso, 2008), 126. For more on the difficulty of finding a representational practice adequate to late capitalism, see Fredric Jameson, "Cognitive Mapping," in Marxism and the Interpretation of Culture, eds. Lawrence Grossberg and Cary Nelson (Champaign, IL: University of Illinois Press, 1988), 347-57.

${ }^{8}$ See Jeff Kinkle and Alberto Toscano, Cartographies of the Absolute, (Winchester, UK: Zero Books, 2015) for a detailed consideration of visual strategies representing phenomena that elude figuration.

${ }^{9}$ Vinzenz Hediger and Patrick Vonderau, "Record, Rhetoric, Rationalization: Industrial Organization and Film," in Films That Work: Industrial Film and the Productivity of Media, eds. Vinzenz Hediger and Patrick Vonderau (Amsterdam: Amsterdam University Press, 2009), 36. For additional scholarship on sponsored film specific to the oil industry, see Rachel Webb Jekanowski, "Fuelling the Nation: Imaginaries of Western Oil in Canadian Nontheatrical Film,"
} 
us about how images do more than merely represent tangible entities. They can inscribe the kinds of abstractions we normally think of as only being expressible in words.

In an essay on Royal Dutch Shell in Films that Work, Rudmer Canjels notes that the oil company's interests are systematically interlaced with "larger political and societal goals" in its films, which thus come to serve as the visual equivalents of written manifestos. ${ }^{10}$ Canjels mentions that Shell films use animated drawings or diagrams to "explain difficult technical processes clearly," but is less clear on the visual means they use to achieve their ideological objectives. ${ }^{11}$ Early in the Cold War, Shell, a multinational corporation, was eager to show host countries like Venezuela that it was "an interested and creative member of the community with a sympathetic understanding of their culture and a sense of public responsibility." 12 A "sense of public responsibility" is an abstract concept difficult to convey visually. Canjels says that the Shell films New Horizons (1949) and Harvest for Tomorrow (1950) show "the impact and development of oil on the Venezuelan economy, while at the same time stimulating the government to start gradually investing the proceeds of oil in social services and industrial development," but does not explain how the films visually depict "impact" or "development" or "stimulation."13 Images of underground rock in API films pin down these nebulous qualities, a process crucial for displaying to audiences the benefits of capitalist society and so achieving the broader ideological goal of cementing it in America. Seeing capitalism by way of looking underground has the effect of suddenly revealing the invisible ideological forces continually acting all around us, as putting on night-vision goggles has the effect of turning the light on a landscape whose opacity was impenetrable before.

\section{Conveying Complex Geological Information Visually}

Images illustrating subsurface geology, including "maps, cross-sections, color slides, and diagrams," began appearing in books and journals starting from the

Canadian Journal of Communication 43, no. 1 (2018): 111-25, and Bob Johnson, Carbon Nation: Fossil Fuels in the Making of American Culture (Lawrence, KS: University of Kansas Press, 2014), 130-62.

${ }^{10}$ Rudmer Canjels, "Films from Beyond the Well: A Historical Overview of Shell Films," in Films That Work, 243.

11 Ibid., 246.

12 Ibid., 246-47.

${ }^{13}$ Ibid., 247. 
late eighteenth century. ${ }^{14}$ Land surveys designed to find resources like building stone, coal, iron, and salt at the turn of the nineteenth century needed to be as legible to lay miners as to scientific specialists, and images had the advantage of compactly conveying information that reams of words might still not be able to communicate as effectively. However, rapid technological advancement within the oil industry at the turn of the twentieth century meant that neither the process of exploring for oil, nor the written and visual records of such prospecting, were as accessible to laymen as they once were. A 1939 Petroleum Technology article compiling four papers on "Seismograph Prospecting for Oil" telegraphs contemporary anxiety surrounding the increasingly arcane nature of geophysical knowledge:

To many people mathematics is a formidable subject, and many are discouraged from studying seismograph prospecting under the mistaken assumption that the mathematical requirements are severe. In the papers presented here there is not a single mathematical equation. We believe that considerable competence in dealing with some of the most important problems of this work can be attained without any mathematical training whatever. At the present time, there is a real need for interpretation of results by persons thoroughly competent to bring geologic experience and imagination to bear on data that are subject to multiple interpretation from a strictly physical viewpoint. ${ }^{15}$

Where a topographical land survey looks like a conventional map, a seismic image in the 1930s would have been a series of serrated lines resembling the jagged scratchings made by the needles used in old-fashioned polygraph tests. Conventional maps bear a reasonably close indexical relation to the phenomena they capture - a bend in a river in real life, for example, is mirrored by a bend in the line representing the river on a map - whereas the pointed peaks and dips in the lines running along a seismogram bear a more tenuous indexical relation to the subsurface geological formations they depict. It is difficult to know what rock deep underground looks like, as we have usually only ever seen two-dimensional representations of it drawn in crosssectional diagrams, but it certainly does not look like the spikes on an electrocardiographic readout monitoring heart activity. The Petroleum

\footnotetext{
${ }^{14}$ Brian Frehner, Finding Oil: The Nature of Petroleum Geology, 1859-1920 (Lincoln, NE: University of Nebraska Press, 2011), 48.

${ }^{15}$ Walter A. English, Frank Ittner, P. C. Kelly, Arthur Nomann, and Willard H. Tracy, "Seismograph Prospecting for Oil," Petroleum Technology 2, no. 2 (May 1939): 1.
} 
Technology article stresses that even experts might not necessarily agree on the significance of visual information they are presented with after a seismic survey. The results are difficult enough for laymen to read, but trained geologists and physicists may also struggle to know which reflections on a record are actually usable for later contour mapping. Varying types of equipment and dynamiting methods that can produce records quite different in appearance from the same territory further dims the records' readability.

Given the complexity entailed in interpreting visualized geophysical data, the Petroleum Technology article and other oil industry literature from the 1930s emphasize the importance of finding better ways to represent subterranean geology. In a paper delivered at the second World Petroleum Congress in Paris in June 1937, the geophysicist E. E. Rosaire approvingly cited a recent visual invention that was helping record seismic waves more efficiently and comprehensibly: the filmstrip. Seismic technology and motion picture technology had been overlapping for the previous few years. In 1926, an Amerada subsidiary called the Geophysical Research Corporation used an old hand-cranked $35 \mathrm{~mm}$ movie camera as part of its seismic survey toolkit, repurposing it into a single-trace recording camera. Timing lines were projected onto the film during surveys by shining a light through slits attached to the prongs of a large tuning fork, just as a clapboard held in front of a movie camera during shooting inscribes film scene and take numbers. ${ }^{16}$ Seismograms were long thin bands of photographic paper reminiscent of filmstrips, anywhere from 100 to 250 feet in length and three to eight inches wide. The jagged lines tracing the shakings of the Earth after dynamite explosions appeared out of recording cameras as either black lines on a white background, or white lines on a black background. The former were made when a light spot oscillated over the photographic paper traveling beneath it to create a sinusoidal pattern, and the latter when light fell everywhere on the paper except for a tiny focused shadow, just as filmstrips record images based on either exposure to or protection from light. ${ }^{17}$ In this way, the spikes on the seismogram resembled the mechanical recordings of a motion-picture camera turned on and then left alone to indiscriminately register whatever passes in front of its lens.

In his 1937 paper, Rosaire noted that "instead of recording the seismograph impulses on a strip of sensitized paper by the usual

\footnotetext{
${ }^{16}$ Charles C. Bates, L. C. (Lee) Lawyer, and Robert B. Rice, Geophysics in the Affairs of Mankind: A Personalized History of Exploration Geophysics (Tulsa, OK: Society of Exploration Geophysicists, 2001), 15.

${ }^{17}$ English et al., 13-14.
} 
galvanometers," a new development in the field marked the pulses "on a film in the same manner that sound tracks are made for talking motion pictures, and so secures a seismograph record which is repeatable, and is also subject to mechanical analysis." 18 Pulses from ten or more seismographs distributed across a terrain, each recording on a discrete sound film, could be combined into one composite record useful for analyzing highly folded and faulted subsurface structures that would be difficult to visualize otherwise. The 1939 Petroleum Technology article points out that geologists cannot be certain of underground structures or it would not be necessary to do geophysical surveys in the first place, and that physicists are "unable to put on a diving helmet and follow a vibration down a couple of miles into the earth and back again and report on what happened as a matter of precise knowledge." ${ }^{19}$ Film technology, however, is a powerful tool to illuminate and clarify what is hard to see.

\section{Representing Seismic Surveys in API Films}

Alongside the films it commissioned for Oil Progress Week, the API blanketed the country with a series of creative local and national observances of the occasion. For seven days every October, the API urged oil companies both big and small to hold open houses at their facilities, making a concentrated effort to convince local communities that they were "good citizens who provide many services to the public." ${ }^{20}$ During Oil Progress Week, the API orchestrated lectures by oilmen and politicians on the efficiency of the industry's practices and its contributions to the American way of life. It arranged lunches and dinners in collaboration with organizations like the "Desk and Derrick Club," a network of female oil-company employees. Employees were encouraged to talk to their neighbours and friends about the industry. Industry spokesmen addressed local civic clubs and school audiences. Materials were provided for local company advertising and media relations activities. Over the course of its 10-year lifespan, Oil Progress Week organizers embraced barbecues, beauty queen contests, building and window displays, parades, placards, posters, radio and television programs, salutes to service-station dealers, special newspaper editions, and trade reviews.

\footnotetext{
${ }^{18}$ E. E. Rosaire, "Developments in Exploration Geophysics Since 1935" (paper presented at the 2nd World Petroleum Congress, Paris, France, June 14-19, 1937).

${ }^{19}$ English et al., 29.

${ }^{20}$ Stephen P. Potter, The American Petroleum Institute: An Informal History (1919-1987) (Washington, DC: American Petroleum Institute, 1990), 15.
} 
The 1949 API film The Last Ten Feet, the first one commissioned for Oil Progress Week, begins with a claim that appears in many films sponsored by the organization: most people are unaware of all the labour that goes on behind the scenes in order to bring oil to them. The average motorist only sees the "ten feet of hose" that connect a service-station gas pump to their car's tank. Behind those last ten feet, however, is an entire industrial infrastructure scattered all across the country and peopled with two million employees working day and night to keep oil consumers' lives running smoothly. The film goes on to deploy moving images' revelatory ability to unveil for audiences the ordinarily invisible, intricate processes in place to produce and refine crude and distribute it among customers. It leads the viewer through these processes in chronological order using black-and-white newsreel-type footage, beginning with geological exploration and drilling upstream, to refineries and tanker transportation downstream.

When delineating the seismic survey process upstream, the film relies on an animated sequence to show white pulses from the dynamite shot traveling down through grey layers of cross-sectioned rock, then bouncing back up to detectors on the surface of the Earth, arranged like four small sheds in a row, which each light up with a bright dot as the reflected waves reach them. Animation allows the film to cut away the Earth and reveal what is normally concealed from view, as slicing into a layer cake exposes the tiers hidden within, and also enables the film to compress complicated procedures distended in space and time into a neat, digestible image. Letters in the API archive show that making sponsored films appeal to nonspecialists through easily comprehensible visual techniques like animation was a paramount concern. Production companies hired to make films on the association's behalf assure API executives that "we approach our topic as laymen." 21 The industrial photographer Robert Yarnall Richie argued in a presentation for the association that comparatively abstract film topics could best be represented visually with animation:

That the history of man's material progress is largely the history of his forward steps in the utilization and direction of energy is, at least to the general public, a novel concept. To be understood and accepted it must be clearly, systematically - and, of course, entertainingly_-formulated. In my opinion, it's only through

${ }^{21}$ Treatment dated May 26, 1964, from Pendulum Productions for the film Energy, American Petroleum Institute Photograph and Film Collection, Archives Center, National Museum of American History, Box 115, Folder 5. 
animation that these three requirements can be joined together in the required unity. ${ }^{22}$

Animation has an affinity for that which is difficult to visualize, frequently incorporated into documentaries to show material things that the camera was not present for, or immaterial phenomena that it would not have been able to capture even if it were present. Animated imagery might be used to recreate a murder in a true-crime documentary, for example, or to represent how food tastes or smells using inchoate colours and shapes. According to the filmmaker Andy Glynne, animation and documentary make for an especially logical pairing when "you're trying to give some kind of representation of individual's internal processes; that is, trying to capture a sense of what the world looks like from within, whether this be mental illness, sorrow, memories, deafness, being a child," and when "you're trying to film the unfilmable. There are certain things we can't film, either because we were not there at the time, or because it's not the kind of thing that a camera could have been present at.

Whether this be the story of someone caught up in a tsunami, a narrative of the Holocaust or other genocide, or the victim of an assault, animation, when paired with a single-person narrative, can often be extremely powerful." ${ }^{23}$ The Last Ten Feet relies on animation to illustrate the interiority that Glynne discusses: its version of showing "what the world looks like from within" by diving into a person's head is instead plunging deep into the Earth's crust and breaking it open to view. Furthermore, animated underground rock takes a nebulous concept that would be challenging for a camera to film-the urgency of finding abundant, low-cost energy to continue fueling American advancement - and crystallizes it into concrete form. An animator has more control over her image than a live-action filmmaker because she crafts it from scratch. She "can therefore achieve such precision in detail and has so much control over representation that, in educational films in particular, a thought can be brought to an exact point, which the use of conventional photographic images does not allow as easily." 24

\footnotetext{
${ }^{22}$ Presentation dated January 9, 1961, by Robert Yarnall Richie, American Petroleum Institute Photograph and Film Collection, Archives Center, National Museum of American History, Box 115 , Folder 9.

${ }^{23}$ Andy Glynne, "Drawn From Life: The Animated Documentary," in The Documentary Film Book, ed. Brian Winston (London: British Film Institute, 2013), 75.

${ }^{24}$ Ramón Reichert, "Behaviorism, Animation, and Effective Cinema: The McGraw-Hill Industrial Management Film Series and the Visual Culture of Management," in Films That Work, 292.
} 
The Last Ten Feet never mentions capitalist versus communist values explicitly, but bringing the "thought" of their ideological battle to an exact point underlies much of the film's sound and images, whether animated or liveaction. "We Americans," the voiceover says over live-action images of offshore rigs, "use twice as much oil every day as all the rest of the world put together, thanks to the ingenuity and resourcefulness of operating oilmen." "We Americans" implicitly sets the United States up as different from and better than other nations, just as the booming U.S. society in Destination Earth poses a striking contrast to the harrowing communism-modeled system on Mars. It is worth nothing that animated Soviet propaganda from the Cold War gleefully derides the highly individualistic, hypercompetitive system exalted by Destination Earth. A film like Mr. Wolf (1949), for instance, is stridently anticapitalist. Made by the animation studio Soyuzmultfilm, Mr. Wolf centers around the family of the titular character: Mr. Wolf is a titan of industry who decides to leave his business behind and move his wife, his son Archie, and his daughter Pamela to the idyllic "Island of Peace." They spend their days lounging in hammocks and reading (Mrs. Wolf finds it all very dull, craving a railway catastrophe or two). However, two reporters who have chased them to the island in pursuit of a story accidentally fall into a pool of crude oil that has bubbled up from the ground. Upon realizing that the island is oil-rich, the Wolfs savagely fight among themselves to lay claim to the reserves first. Capitalist competitiveness is shown to be so pervasive that it even infiltrates and corrupts families, turning greedy parents on children, and siblings against each other. It is a dog-eat-dog, or Wolf-eat-Wolf, world.

Unlike $M r$. Wolf, in which oil lies around freely available in huge surface pools, The Last Ten Feet emphasizes the elusiveness of oil, thus making the capitalist system seem all the more remarkable for creating the conditions necessary to track it down, pull it out of the ground, and pour it into just about everything a human being touches, from cosmetics to plastics, dyes, insecticides, medicines, nylons, and waxes. ${ }^{25}$ The world of capitalism may be cruel, but it compensates for its cruelty somewhat with a cornucopia of

\footnotetext{
${ }^{25}$ Matthew Yeomans describes the difficulty of getting through an ordinary day without the fuel in Oil, his snapshot of the petroleum business. Driving is out of the question, of course, but so are brushing his teeth, shaving, using a shower curtain, wearing either glasses or contact lenses, dressing his six-month-old son in disposable diapers, wearing sneakers, walking on asphalt, paying with credit or debit cards, and using computers, telephones, CDs, or DVDs. As he says, everything from bandages to blenders, garbage bags to glue, pacemakers to pantyhose got its start in oil. He cannot even take an aspirin at the end of a trying day because aspirin is "another proud legacy of oil." See Matthew Yeomans, Oil: Anatomy of an Industry (New York: The New Press, 2004), xii-xiii.
} 
consumer goods. The Last Ten Feet's voiceover says that "only actual drilling can make it a certainty" if oil is underground, as "great machines can take oilmen to the most forbidden areas, but science has not yet given them a divining rod for oil. Every attempt, every probing of the Earth is still a gamble." ${ }^{26}$ The voiceover delivers success-rate statistics similar to those found in Destination Earth, adding that the chances are only one in five of bringing in a producing well and making good on a capital investment of up to a million dollars. The lone wildcatter exploring "forbidden" frontiers, in other words, is a modern-day cowboy, gamely getting up the four times out of five he is knocked down to resume his fight to strengthen America's industrial infrastructure, and so fortify the Free World. The Wolfs were shown to be selfish, but the tireless cowboy in American propaganda works selflessly for the greater good.

The resonances between The Last Ten Feet and Destination Earth also ripple into other films from later Oil Progress Weeks, such as 1950's 24 Hours of Progress. As I have said, films sponsored by the oil industry are highly standardized. As with The Last Ten Feet, 24 Hours of Progress links the mythic American frontier to the country's oil industry. Narrated by Hollywood actor Ralph Bellamy — who memorably played an oafish Oklahoma oilman in the screwball comedy The Awful Truth (1937) — the film's voiceover says that "the pioneers who spread across our continent tamed the land for living," just as the oil industry's free enterprising assures American progress "from the Conestoga wagon to the constellation." Films sponsored by the oil industry make it seem exclusively responsible for America's development, minimizing the role of other industries. The Last Ten Feet's voiceover, for instance, claims that it is "no coincidence" that the breathtaking improvement in American quality of life during the 90-year period between 1859-1949 overlaps perfectly with the history of the oil business. American advancement is measured in the production of petroleum, comprising "more than five million barrels of crude oil" drawn from the Earth every day. The oil industry is America: as the voiceover in the Ethyl Corporation's Gasoline for Everybody (1947) says, "Do you realize what gasoline means for this country? It has added a new freedom to our lives. The freedom of movement. Of individual transportation. Anywhere, anytime, for everybody in America." Colonel Cosmic drives the oil-as-freedom-and-democracy theme home in Destination Earth as well. He initially thinks that the superb cars he sees in America are "state limousines," saying "Surely these vehicles must be the property of the highest officials. I

26 “The Last Ten Feet," Indiana University Libraries Moving Image Archive, accessed March 1, 2018, http://collections.libraries.india.edu/IULMIA/items/show/1575. 
was wrong. It seems that almost everybody in this country has one of thosethey call them automobiles." Oil's benefits, in other words, are not limited to elites like Ogg the Exalted, but evenly distributed among all citizens. If the oil industry is America, and the industry begins underground, subterranean rock is the incubator of cherished American values like equality and individual liberty.

24 Hours of Progress visualizes that elusive yet vital underground space through a long sequence set in a wildcatter's office, where every available surface is covered in contour maps. Bellamy's voice shifts to another actor's voice playing the wildcatter, who says that poring over representations of "what the Earth looks like underground" helps him "take some of the guesswork out of what's still a big gamble." The wildcatter goes on to talk the film's audience through the seismic survey process in detail, his voice laid over footage of a geophysical crew enacting each of the steps he describes:

The mapping starts when we drill shallow holes every few hundred yards. These aren't oil wells, just holes that go down about 75 or 100 feet. In 'em we put some dynamite, and then we fill 'em up with water. You see, we map with a seismograph, the same gadget they use to measure earthquakes with. The dynamite makes our earthquake. The sound waves that echo off the underground rock give us a picture [of] what it's like down there.

The sequence culminates in a close-up of a geophysicist's hands over several long seismogram strips, measuring multiple rows of jagged white lines on a dark background using a pen and set square. Bellamy's voice takes over again. By mentioning that "a single well can cost up to a million dollars," the voiceover in 24 Hours of Progress exalts the oil industry, as The Last Ten Feet did by citing the same fact. That the industry has sufficient resources to throw away such a staggering sum on four out of five attempts to drill underground for oil also, presumably, means that it is powerful enough to serve as an impenetrable bulwark protecting America from all foreign threats, whether the Axis powers in the past, or the Soviet Union in the future. Oil companies energetically competing with each other in the free market together solve problems in "our inventive age, be it peaceful or otherwise." Visualizing the literal rock from which oil springs is thus an effective device to help the 24 Hours audience imagine oil as the figurative bedrock of American security. It matters that a drilling bit "chewing at the rock beneath the bayou" in the Gulf 
of Mexico gets a hundred feet closer to oil every day because petroleum-based military plane and ship fuels safeguard the nation. ${ }^{27}$

Oil's weaponization in 24 Hours of Progress continues in the following year's Oil Progress Week film, Man on the Land (1951). Largely live-action sponsored films like the API's The Last Ten Feet, or Chevrolet's Down the Gasoline Trail (1935), or Standard Oil of Indiana's The Inside Story of Modern Gasoline (1946), occasionally lean on an animated sequence to visualize processes that would otherwise be difficult to represent using live action, such as sound waves bouncing off underground rock during seismic surveys, or a drop of gasoline journeying from a car's gas tank to its exhaust pipe, or the invisibly small carbon atoms found in crude oil. Man on the Land, on the other hand, is entirely animated, using that visual tool to pack several millennia of world history into picturizable form. Man on the Land portrays oil as the latest chapter in a long story of man imposing control over his environment using weaponry, from prehistoric hunter-gatherers spearing mammoths for food to modern farmers keeping weeds and insects at bay using petroleum-derived pesticides.

Like its predecessors, Man on the Land lingers on the year 1859, when former railroad conductor Edwin Drake first deliberately drilled down for oil rather than simply collecting it after it had already bubbled up through the ground. The voiceover in The Last Ten Feet discusses Drake's pioneering well, or "Drake's folly," as "wiseacres" called it, praising him for having had the vision to transform what seemed like a futile endeavor into a triumph. Man on the Land features a character dubbed the Scoffer. Like the hecklers and catcallers who besieged Drake in real life, the Scoffer repeatedly denigrates mankind's achievements throughout history. ${ }^{28}$ When a cartoon version of Drake is shown "punching a hole in the ground" for oil, he says, "well, what good is it? You can burn it in a lamp, but that's all." Au contraire, and like other API films, Man on the Land shows oil to have a dazzling panoply of applications, all made possible by the moment of drilled oil's eruption from the ground. "It'll never work!" the Scoffer exclaims. "The whole idea'll blow up sky high!" A spectacular gusher immediately follows. The gusher allows Man on the Land to emphasize the essential instant of oil's torsion from underground interiority to surface-level exteriority.

27 “24 Hours of Progress,” National Film Preservation Foundation, accessed March 1, 2018, https://www.filmpreservation.org/sponsored-films/screening-room/24-hours-of-progress-1950.

${ }^{28}$ Brian Black, Petrolia: The Landscape of America's First Oil Boom (Baltimore, MD: The Johns Hopkins University Press, 2000), 31. 
Underground rock signifies huge potential, as it holds "the power to revolutionize man's way of life," but that potential cannot be realized until oil is unleashed from it. The difference between capitalist and communist systems, so the film's logic goes, is the difference between having the means to release oil's potential, and lacking those means. "Hundreds of companies were formed, little and big, all competing for a share of the business," its voiceover says. Free-market competition is what hacks the oil out of the ground, and creates its plethora of uses. The market's ever-evolving drilling methods for tapping oil pools miles underground ensure "our strength, and preserve our climate of freedom." The spoken voiceover in Man on the Land is interspersed with a sung voiceover, and the film closes with the sung words "you cultivate your freedom like you cultivate your land / You guard against its enemies on each and every hand." 29 As its title suggests, the idea of "land" anchors the film. Land - comprising subterranean rock, and its topmost layer of soil-are shown to sustain America's oil drillers and farmers, thus guaranteeing that the country can rebuff its Soviet enemy. The war between Soviet and American values is waged in the ground.

29 “Man on the Land," Internet Archive, accessed March 1, 2018, https://archive.org/details/ManOnTheLand. 


\section{Works Cited}

"24 Hours of Progress.” National Film Preservation Foundation. Accessed March 1, 2018. https://www.filmpreservation.org/sponsoredfilms/screening-room/24-hours-of-progress-1950.

Bates, Charles C., L. C. (Lee) Lawyer, and Robert B. Rice. Geophysics in the Affairs of Mankind: A Personalized History of Exploration Geophysics. Tulsa, OK: Society of Exploration Geophysicists, 2001.

Black, Brian. Petrolia: The Landscape of America's First Oil Boom. Baltimore, MD: The Johns Hopkins University Press, 2000.

Canjels, Rudmer. "Films from Beyond the Well: A Historical Overview of Shell Films." In Films That Work: Industrial Films and the Productivity of Media, edited by Vinzenz Hediger and Patrick Vonderau, 243-55. Amsterdam: Amsterdam University Press, 2009.

“Destination Earth.” Internet Archive. Accessed March 1, 2018. https://archive.org/details/Destinat1956.

English, Walter A. Frank Ittner, P. C. Kelly, Arthur Nomann, and Willard H. Tracy. "Seismograph Prospecting for Oil," Petroleum Technology 2, no. 2 (May 1939): 1-29.

Frehner, Brian. Finding Oil: The Nature of Petroleum Geology, 1859-1920. Lincoln, NE: University of Nebraska Press, 2011.

Glynne, Andy. "Drawn From Life: The Animated Documentary." In The Documentary Film Book, edited by Brian Winston, 73-75. London: British Film Institute, 2013.

Hediger, Vinzenz and Patrick Vonderau. "Record, Rhetoric, Rationalization: Industrial Organization and Film." In Films That Work: Industrial Film and the Productivity of Media, edited by Vinzenz Hediger and Patrick Vonderau, 35-50. Amsterdam: Amsterdam University Press, 2009.

Jameson, Fredric. “Cognitive Mapping." In Marxism and the Interpretation of Culture, edited by Lawrence Grossberg and Cary Nelson, 347-57. Champaign, IL: University of Illinois Press, 1988.

“The Last Ten Feet.” Indiana University Libraries Moving Image Archive. Accessed March 1, 2018. http://collections.libraries.india.edu/IULMIA/items/show/1575. 
Jekanowski, Rachel Webb. "Fuelling the Nation: Imaginaries of Western Oil in Canadian Nontheatrical Film." Canadian Journal of Communication 43, no. 1 (2018): 111-25.

Johnson, Bob. Carbon Nation: Fossil Fuels in the Making of American Culture. Lawrence, KS: University of Kansas Press, 2014.

Kinkle, Jeff and Alberto Toscano. Cartographies of the Absolute. Winchester, UK: Zero Books, 2015.

"Man on the Land." Internet Archive. Accessed March 1, 2018. https://archive.org/details/ManOnTheLand.

Nixon, Rob. Slow Violence and the Environmentalism of the Poor. Cambridge, MA: Harvard University Press, 2011.

Potter, Stephen P. The American Petroleum Institute: An Informal History (1919-1987). Washington, DC: American Petroleum Institute, 1990.

Prelinger, Rick. The Field Guide to Sponsored Films. San Francisco: National Film Preservation Foundation, 2006.

Rancière, Jacques. The Future of the Image. New York: Verso, 2008.

Reichert, Ramón. "Behaviorism, Animation, and Effective Cinema: The McGraw-Hill Industrial Management Film Series and the Visual Culture of Management." In Films That Work: Industrial Film and the Productivity of Media, edited by Vinzenz Hediger and Patrick Vonderau, 283-302. Amsterdam: Amsterdam University Press, 2009.

Rosaire, E. E. "Developments in Exploration Geophysics Since 1935." Paper presented at the 2nd World Petroleum Congress. Paris, France, June 1419, 1937.

Sekula, Allan. Fish Story. Düsseldorf: Richter Verlag, 2002.

Steimatsky, Noa. "What The Clerk Saw: Face To Face With The Wrong Man." Framework 48, no. 2 (Fall 2007): 111-36.

Watts, Michael. "Oil Frontiers: The Niger Delta and the Gulf of Mexico." In Oil Culture, edited by Ross Barrett and Daniel Worden, 189-210. Minneapolis, MN: University of Minnesota Press, 2014.

Yeomans, Matthew. Oil: Anatomy of an Industry. New York: The New Press, 2004. 